\title{
SUSCEPTIBILITY OF FIVE FOREST SPECIES TO Coptotermes gestroi ${ }^{1}$
}

\author{
José Hildefonso de Souza ${ }^{2}$, Elen de Lima Aguiar Menezes ${ }^{3}$, Robson Mauri ${ }^{4}$ e Euripedes Barsanulfo Menezes ${ }^{4}$
}

\begin{abstract}
Termites are well known for their ability to damage wood and various types of wood-derived products. This study was performed in the municipality of Seropédica, Rio de Janeiro state, Brazil, with the objective of evaluating the susceptibility of the wood of five different forest species to the activity of the Asian subterranean termite, Coptotermes gestroi. Wood stakes from the following forest species were used as specimens: pine (Pinus sp., Pinaceae), Brazil nut (Bertholletia excelsa, Lecythidaceae), cabbage angelin (Andira inermis, Leguminosae-Papilionoideae), maçaranduba (Manilkara huberi, Sapotaceae) and pink ipêe (Tabebuia avellanedae, Bignoniaceae). The stakes, with dimensions of $2 \mathrm{~cm} \times 2 \mathrm{~cm} \times 16 \mathrm{~cm}$, were subjected to the activity of $\mathrm{C}$. gestroi from September 2, 2006 to June 2, 2007. The experimental design consisted of randomized blocks with four replications in an $11 \times 5 \times 3$ factorial arrangement. Twelve stakes of each of the five forest species were installed at each of eleven sites, totaling 660 stakes. Three evaluations were performed, at 90, 180 and 270 days after stake installation. The results indicated that the pine, Brazil nut and cabbage angelin stakes were more susceptible to $\mathrm{C}$. gestroi attack, while the pink ipê and maçaranduba stakes suffered no significant damage from this termite. There was a significant negative correlation between the wood consumption rate and the wood density of the species studied. The woods most susceptible to $\mathrm{C}$. gestroi attack presented moderate to low densities and therefore less resistance, as in the case of pine and cabbage angelin.
\end{abstract}

Keywords: Isoptera, Rhinotermitidae, subterranean termites and termite damage.

\section{SUSCETIBILIDADE DE CINCO ESSÊNCIAS FLORESTAIS A Coptotermes gestroi}

\begin{abstract}
RESUMO - Os térmitas são bem conhecidos por sua capacidade de danificar madeira e vários tipos de produtos derivados. O estudo foi realizado no município de Seropédica, RJ, com o objetivo de avaliar a susceptibilidade da madeira de cinco essências florestais à ação do cupim subterrâneo asiático, Coptotermes gestroi. Como corpos-de-prova foram utilizados estacas de madeiras das seguintes essências florestais: pinho (Pinus sp.) (Pinaceae), castanheira (Bertholletia excelsa) (Lecythidaceae), angelim (Andira inermis) (Leguminosae-Papilionoideae), maçaranduba (Manilkara huberi) (Sapotaceae) e ipê (Tabebuia avellanedae) (Bignoniaceae). As estacas, com dimensões de $02 \mathrm{~cm}$ x $02 \mathrm{~cm}$ x $16 \mathrm{~cm}$, foram submetidas à ação de C. gestroi, no período de 02 de setembro de 2006 a 02 de junho de 2007. O delineamento do experimento foi em blocos ao acaso com quatro repetições em arranjo fatorial $11 \times 5 \times 3$, composto por 11 locais, cada um incluindo as cinco espécies florestais, totalizando 660 estacas e as avaliações efetuadas aos 90, 180 e 270 dias após a instalação das estacas. Os resultados indicaram que as estacas de pinho, castanheira e angelim são mais susceptíveis ao ataque de C. gestroi, enquanto que as estacas de ipê e maçaranduba não sofreram danos significativos por esse térmita. Houve correlação significativa e negativa entre as taxas de consumo de madeira e a densidade da madeira das essências estudadas. As madeiras mais susceptíveis ao ataque de C. gestroi apresentaram densidades moderadas a leves, portanto, menos densas e menos resistentes, como o pinho e a castanheira.
\end{abstract}

Palavras-chave: Rhinotermitidae, cupim subterrâneo e danos.

\section{INTRODUCTION}

According to Oliveira et al. (1986), the desirable wood characteristics of certain tree species, including hardwoods such as jacaranda (Jacaranda spp.), mahogany (Swietenia spp.) and angico (Anadenanthera spp.), guarantee these species a range of uses in both rural and urban settings, and they have played a prominent role in the development of civilization since the origin of humanity. Among these characteristics,

\footnotetext{
${ }^{1}$ Recebido em 06.05.2008 e aceito para publicação em 23.06.2009.

${ }^{2}$ Programa de Pós-Graduação em Produção Vegetal/Fitossanidade da UENF-RJ. E-mail: <jhilde @ bol.com.br>.

${ }^{3}$ Coordenadora do Programa de Pos-graduação em Fitossanidade e Biotecnologia Aplicada-UFRRJ/IB/DEnF. E-mail: <ppgfitoba@ufrrj.br>.

${ }^{4}$ Universidade Federal Rural do Rio de Janeiro - UFRRJ, Instituto de Biologia, Seropédica-RJ. E-mail: <ebmen @ uol.com.br>.
} 
the following are notable: elevated mechanical resistance in relation to mass, machinability, high chemical resistance, good thermal and electrical isolation properties and natural diversity in textures and colors to satisfy the various tastes of consumers.

One factor that limits the utilization of wood for various end products is, without a doubt, its low natural durability. Knowledge of the natural resistance or susceptibility of wood is therefore of fundamental importance for recommendations concerning its most appropriate uses, particularly in the furniture and civil construction industries. Not only does this help to avoid unnecessary costs for the replacement of parts, but it also reduces the impact on residual forests by reducing deforestation (PAES et al., 2004)

Due to the organic nature of its constituent polymers, wood can have its durability compromised by a variety of biological, physical and chemical agents. By virtue of its structure and chemical composition, it suffers from attacks by various deteriorative organisms, principally fungi and termites (HUNT and GARRATT, 1967; CAVALCANTE, 1982; LOPEZ and MILANO, 1986; TREVISAN et al., 2007). Termites use wood as food and as a physical medium for shelter and nesting, and thus, in any circumstance, they cause damage to the wood. In contrast to fungi, termites destroy wood by burrowing in the wood structure to create galleries, consequently altering its mechanical resistance.

Brazil possesses one of the most diverse termite fauna in the world. Termites are social insects of the order Isoptera, which contains roughly 3000 catalogued species throughout the world. In Brazil, approximately 300 species distributed in four families (Kalotermitidae, Serritermitidae, Termitidae and Rhinotermitidae) have been recorded. Known for their economic importance as pests in wood and other cellulosic materials, termites have also attracted the attention of many scientists due to their unique social system. Not only do they cause considerable economic damage in tropical urban areas, but they also play an essential role in the processes of decomposition and nutrient recycling (CONSTANTINO, 1999). The basic food source of termites is cellulosic and lignocellulosic material of different forms: live or dead wood in different stages of decomposition, grasses, roots, seeds, herbivore feces, humus, manufactured goods, etc. (BERTI FILHO, 1995). However, by virtue of modernization and great advances in the agricultural sector, large areas have been degraded

R. Árvore, Viçosa-MG, v.33, n.6, p.1043-1050, 2009 and natural ecosystems altered, making some termite species a great menace to humans and imposing a greater relevance on studies of termites.

In this context, the objective of the present study is to evaluate the susceptibility of five different wood types to attack by the Asian subterranean termite, Coptotermes gestroi, for a period of 270 days under field conditions.

\section{MATERIALS AND METHODS}

The experiment was set up on September 2, 2006, on the campus of the Universidade Federal Rural do Rio de Janeiro (UFRRJ), in Seropédica, RJ ( $22^{\circ} 45^{\prime} \mathrm{S}$, $43^{\circ} 41^{\prime} \mathrm{W}$; altitude $33 \mathrm{~m}$ ) at the following sites: near the Departments of Geology (DG) and Mathematics [Pytágoras Building (PYT)], the Institutes of Biology (IB), Human and Social Sciences (ICHS), Chemistry (PQ), Technology (IT) and Veterinary Science (IV), the Male Dormitory 5 (M5), the Central Library (BC), the Central Pavilion (P1) and the residential area known as the Ecological neighborhood (RE) (belonging to UFRRJ and Embrapa Agrobiology). The minimum distance between these points is roughly $300 \mathrm{~m}$, with the exception of $\mathrm{BC}$, which is located about $50 \mathrm{~m}$ from $\mathrm{P} 1$. Selection of these sites was based on the studies of Bicalho (2000) and Peralta (2001), which identified the first natural infection centers of subterranean termites in this area.

The predominant climate in the region is hot and humid, without a pronounced winter (the average temperature of the coldest month is $15.7^{\circ} \mathrm{C}$ ), and the rainfall regime is distinguished by the presence of a rainy period during the summer and a dry period during the winter (PESAGRO-RIO, 1990).

Wood stakes $(2 \mathrm{~cm} \times 2 \mathrm{~cm} \times 16 \mathrm{~cm})$ from the following forest species were used as specimens: pine (Pinus sp., Pinaceae), Brazil nut (Bertholletia excelsa, Lecythidaceae), cabbage angelin (Andira inermis, Leguminosae-Papilionoideae), maçaranduba (Manilkara huberi, Sapotaceae) and pink ipê (Tapebuia avellanedae, Bignoniaceae). All five species are widely used in civil construction and furniture production. The wood samples were obtained in the municipality of Seropédica (km 49 on the old RioSão Paulo highway and current BR 465 highway) and on the UFRRJ campus. Of these forest species, only pine is considered exotic and was used as an 
indicator of termite activity (Bultman and Southwell, 1976). Identification was performed by means of the distinctive color of the wood of each species as well as by numbering of the stakes.

The experiment was set up in random blocks with four replicates in an $11 \times 5 \times 3$ factorial arrangement. Four replicates were used for each combination of forest species, site and evaluation date (one stake per replicate). Thus, twelve stakes of each of the five wood species were installed at each of eleven sites, totaling 660 stakes. Three evaluations were performed, at 90, 180 and 270 days after installation of the stakes.

Each stake was weighed twice, once before the installation of the experiment (initial weight) and once at the end of its collection period (final weight). After the determination of the initial weight, the samples were immersed in water for 24 hours in plastic containers with a capacity of 20 liters. Next, the stakes were buried vertically at each site at a depth of $20 \mathrm{~cm}$ and a spacing of $8 \mathrm{~cm}$ according to the methodology of Edwards and Mills (1986). Installation was performed with the aid of a posthole digger and brick trowel. Each stake remained in the soil for either 90, 180 or 270 days. The susceptibility of the wood to subterranean termite activity was determined based on the mass of the wood stakes consumed by these insects, which was calculated as the difference between the initial and final weights of the stakes.

The density of the different species of wood was determined using the stereometry method by immersion, as proposed by Vital (1984). In this method, the volume of the stake is determined by the variation in liquid weight. Each stake was immersed in water in a 1000$\mathrm{ml}$ graduated cylinder whose volume was filled with water to maximum capacity. The cylinder was then placed on a precision electronic balance (BG-1000/ Gehaka), which registered the weight of the initial volume. Next, the stake was removed, the corresponding final weight was obtained and the volume of the stake was determined by the difference. After obtaining the volume, the stakes were placed in a drying oven for 24 hours at $100^{\circ} \mathrm{C}$ and then in a desiccator for 30 minutes for subsequent weighing to obtain dry weight (LENZ and ZI-RANG, 1985). The average density of the wood was calculated by the following equation: $\mathrm{D}=\mathrm{M} / \mathrm{V}$, where $\mathrm{D}=$ mean density $\left(\mathrm{g} . \mathrm{cm}^{-3}\right), \mathrm{M}=$ mean dry mass $(\mathrm{g})$ and $\mathrm{V}=$ mean volume $\left(\mathrm{cm}^{3}\right)$.
The variables were subjected to ANOVA (analysis of variance) using the program SISVAR v.4.5. The averages of the treatments were compared using the Scott-Knott test at a $5 \%$ probability level. Linear regression analysis was used to determine the functional relationship between the rate of wood consumption by subterranean termites and the density of the wood. The consumption rate was determined by the difference between the initial and final weights of the stakes at 270 days after installation.

\section{RESULTS AND DISCUSSION}

The wood stakes from the five forest species studied were infested by the Asiatic subterranean termite, Coptotermes gestroi (Wasmann) (Isoptera: Rhinotermitidae). The presence of basidiomycetes (wood decomposing fungi) was also observed, along with other insects that do not damage wood such as ants, cockroaches and beetles. According to Hunt and Garratt (1967), Cavalcante (1982) and Oliveira et al. (1986), the decay of wood is a chemical process caused by rot fungi (xylophagous fungi). These microorganisms attack the cell walls, irreversibly altering the physical-mechanical properties and compromising wood resistance. According to Sands (1969), the environment of subterranean termites normally includes a wide variety of wood degrading fungi, some of which compete with the termites for cellulosic material as a food source. In general, the Rhinotermitidae benefit from association with these fungi. For example, Lentinus pallidus Berk. \& Curt. degrades compounds in the core of Pinus caribaea that are toxic to Coptotermes niger Snyder, making this the preferred site for feeding and nesting of the latter species (WILLIAMS, 1965). On the other hand, some wood degrading fungi produce compounds that are toxic or repellent to the termites (SANDS, 1969). Ruyooka (1979) showed that wood decomposed by the fungus Gloeophyllum trabeum (Pers.) was repellent to the subterranean termite Nasutitermes exitiosus (Hill). In this context, it appears that the basidiomycete fungi that infected the wood stakes in the present study made them more attractive to $C$. gestroi.

Wood from Pinus presented the lowest mean density $\left(0.42{\mathrm{~g} . \mathrm{cm}^{-3}}^{-3}\right.$, proving to be a lightweight wood, as stated by Trugilho et al. (1990). The native species (Brazil nut and cabbage angelin) presented intermediate values of wood density ( 0.70 and $0.78 \mathrm{~g} . \mathrm{cm}^{-3}$, respectively), agreeing with Lorenzi (1992), who classified these woods

R. Árvore, Viçosa-MG, v.33, n.6, p.1043-1050, 2009 
as moderately heavy. Wood from pink ipê and maçaranduba was the most dense (1.00 and 1.04 g.cm ${ }^{3}$, respectively); these woods were classified as very heavy by Lorenzi (1992).

The feeding behavior of $C$. gestroi was influenced by wood density, which was directly related to consumption rate (Figure 1). The greater the wood density, the less was consumed by $C$. gestroi. Therefore, this termite species showed a preference for the less dense woods over the more dense ones. This behavior was similar to that reported for Reticulitermes flavipes Kollar (Rhinotermitidae) by Behr et al. (1972), who observed a negative correlation between wood density and consumption. In experiments conducted in the forests of Panama, Bultman and Southwell (1976) studied the natural resistance of the wood of 114 arboreal species and concluded that density is one of the factors that give resistance to the wood; the more dense and heavy woods presented greater natural durability and resistance to infestation by subterranean termites (including $C$. niger). When analyzing the natural resistance of 43 tropical arboreal species in laboratory conditions, Bultman et al. (1979) observed that Pinus elliotti (with a mean density of $0.54-0.59$ g.cm ${ }^{-3}$ ) was highly damaged by
Coptotermes formosanus Shiraki, while Manilkara multinervis (1.09 g. $\mathrm{cm}^{-3}$ ) was not damaged by these subterranean termites during 56 days of exposure.

These results corroborate the statements of Bultman and Southwell (1976), Bultman et al. (1979) and Abreu and Silva (2000) that termites prefer less dense woods due to the mechanical ease of their breakdown. It is important to highlight that wood density is not the only factor that provides resistance to termites. According to Bultman and Southwell (1976), Moore (1979) and Barbosa et al. (2003), the high resistance of some wood species to termites can be explained by the properties of their chemical components because there is a close relationship between the percentage of toxic extracts and the natural durability of the wood. According to Tsunoda (1990), studies on wood extracts are valuable for understanding resistance to biodegradation.

Differences were observed among sites in the mass of the wood stakes consumed by $C$. gestroi for each evaluation period (Table 1 ). This result may be explained in part by the foraging behavior of C. gestroi. Recent experiments have shown that termites do not conform to a homogenous distribution among different food sources that are being consumed by the same colony

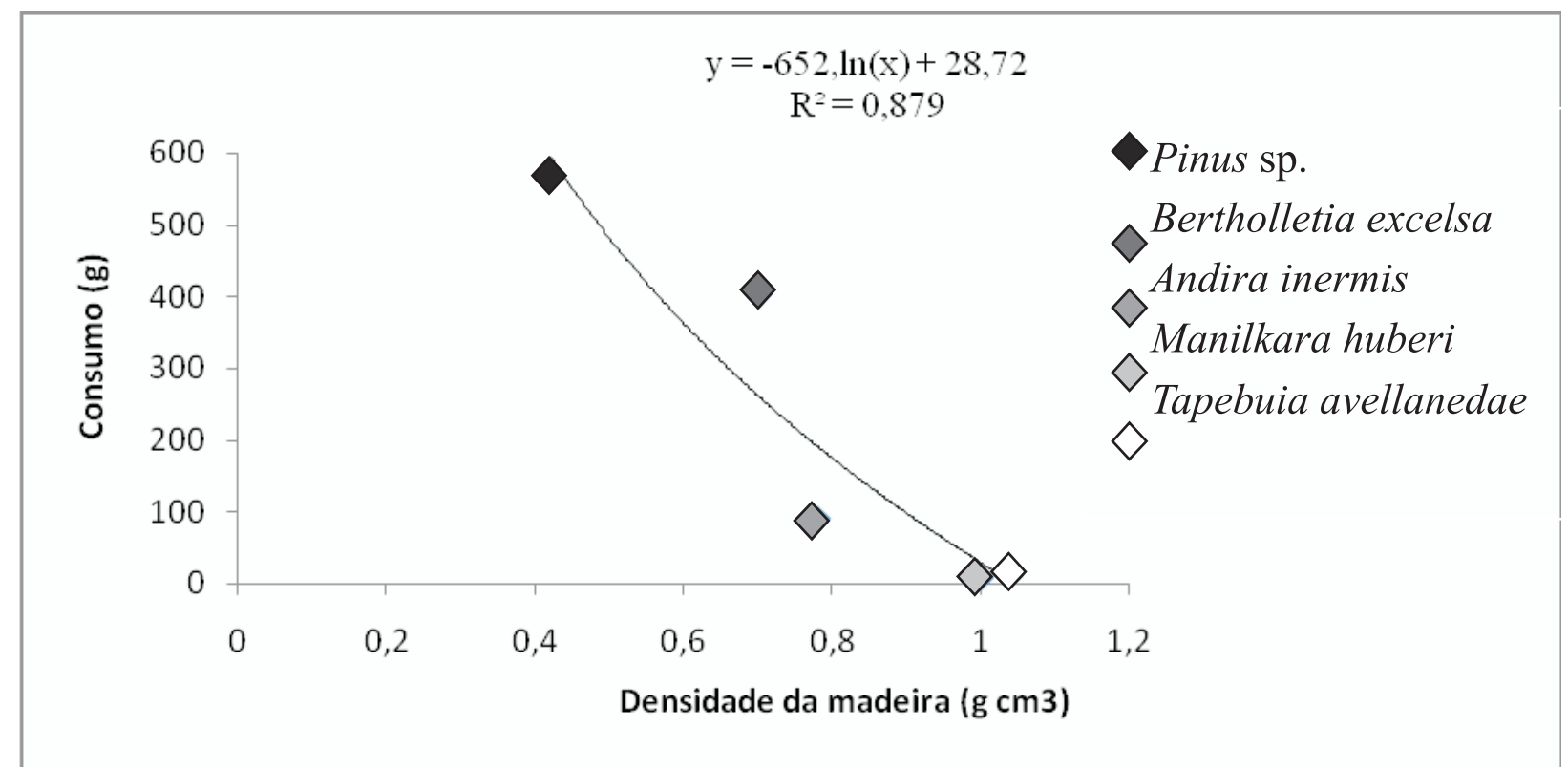

Figura 1 - Influência da densidade da madeira na taxa de consumo (em gramas) das estacas de madeira de cinco essências florestais por C. gestroi.

Figure 1 - Influence of the wood density on the consumption rates (in grams) of the wooden stakes of five forest species by $C$. gestroi.

R. Árvore, Viçosa-MG, v.33, n.6, p.1043-1050, 2009 
(EVANS, 2002; LONG and THRONE, 2006). However, each site may have been occupied by different colonies of $C$. gestroi, considering that all sites were separated by at least $300 \mathrm{~m}$ (except for BC and P1, which were separated by $40 \mathrm{~m}$ ) and that the foraging castes (particularly the workers) of this species can wander up to $100 \mathrm{~m}$ and present a foraging area of 172.5 to $5235 \mathrm{~m}^{2}$ (ARAB et al., 2005).

At 90 days, pine was consumed significantly more by $C$. gestroi than wood of the other forest species at P1 (Table 1). At this evaluation date, consumption of pine and Brazil nut was similar at IV, while consumption of pine, Brazil nut and angelin stakes was similar and significantly greater than consumption of maçaranduba and pink ipê at BC. At the other locations, there was no significant difference among the five forest species in the mass consumed. At 180 days, pine was consumed significantly more than the other species at BC, M5 and $\mathrm{P} 1$. The consumption of pine and Brazil nut stakes was equal and greater than that of the other species at PYT and IGHS. There was no significant difference in the consumed mass of pine, Brazil nut and cabbage angelin stakes installed at IT, IB and DG, yet consumption of these species was significantly greater than that

Tabela 1 - Massa consumida (em grama) das estacas de madeira de cinco essências florestais por C. gestroi nos diferentes locais e nas três épocas de avaliação. Seropédica - RJ, setembro 2006 a junho de 2007.

Table 1 - Consumed mass (in gram) of the wooden stakes of five forest species by $\boldsymbol{C}$. gestroi in the different localities and at three times of evaluation. Seropédica - RJ, September, 2006 to June, 2007.

\begin{tabular}{|c|c|c|c|c|c|c|}
\hline \multirow[t]{2}{*}{ Local } & \multirow[t]{2}{*}{ Época } & \multicolumn{5}{|c|}{ Essência florestal } \\
\hline & & pinho & castanheira & angelim & maçaranduba & ipê \\
\hline \multirow[t]{3}{*}{$\mathrm{RE}$} & 90 & $0 \mathrm{a}$ & $0 \mathrm{a}$ & $0 \mathrm{a}$ & $0 \mathrm{a}$ & $0 \mathrm{a}$ \\
\hline & 180 & $0 \mathrm{a}$ & $0 \mathrm{a}$ & $0 \mathrm{a}$ & $0 \mathrm{a}$ & $0 \mathrm{a}$ \\
\hline & 270 & $0 \mathrm{a}$ & $0 \mathrm{a}$ & $0 \mathrm{a}$ & $0 \mathrm{a}$ & $0 \mathrm{a}$ \\
\hline \multirow[t]{3}{*}{ PYT } & 90 & $0,75 \mathrm{a}$ & $0,25 \mathrm{a}$ & $0 \mathrm{a}$ & $0 \mathrm{a}$ & $0,25 \mathrm{a}$ \\
\hline & 180 & $2,25 \mathrm{a}$ & 5,25 a & $0,25 \mathrm{~b}$ & $0 \mathrm{~b}$ & $0 \mathrm{~b}$ \\
\hline & 270 & $14,5 \mathrm{a}$ & $5,0 \mathrm{~b}$ & $1,25 \mathrm{c}$ & $0 \mathrm{c}$ & $1,35 \mathrm{c}$ \\
\hline \multirow[t]{3}{*}{ IV } & 90 & $1,0 \mathrm{a}$ & $1,75 \mathrm{a}$ & $0 \mathrm{a}$ & $0 \mathrm{a}$ & $0 \mathrm{a}$ \\
\hline & 180 & $2 \mathrm{a}$ & $1,35 \mathrm{a}$ & $0,5 \mathrm{a}$ & $0 \mathrm{a}$ & $0 \mathrm{a}$ \\
\hline & 270 & $10,65 \mathrm{a}$ & $5,01 \mathrm{~b}$ & $0,25 \mathrm{c}$ & $0 \mathrm{c}$ & $0 \mathrm{c}$ \\
\hline \multirow[t]{3}{*}{ I T } & 90 & $0 \mathrm{a}$ & $0,75 \mathrm{a}$ & $0 \mathrm{a}$ & $0 \mathrm{a}$ & $0 \mathrm{a}$ \\
\hline & 180 & $2,85 \mathrm{a}$ & $3,75 \mathrm{a}$ & $1,25 \mathrm{a}$ & $0 \mathrm{~b}$ & $0 \mathrm{~b}$ \\
\hline & 270 & 8,0 a & $3,75 \mathrm{~b}$ & $0,75 \mathrm{c}$ & $0 \mathrm{c}$ & $0 \mathrm{c}$ \\
\hline \multirow[t]{3}{*}{ ICHS } & 90 & $0 \mathrm{a}$ & $0 \mathrm{a}$ & $0 \mathrm{a}$ & $0 \mathrm{a}$ & $0 \mathrm{a}$ \\
\hline & 180 & $4,5 \mathrm{a}$ & $1,85 \mathrm{a}$ & $0 \mathrm{~b}$ & $0 \mathrm{~b}$ & $0 \mathrm{~b}$ \\
\hline & 270 & $5,6 \mathrm{a}$ & $2,35 \mathrm{~b}$ & $2,25 \mathrm{~b}$ & $0 \mathrm{c}$ & $0 \mathrm{c}$ \\
\hline \multirow[t]{3}{*}{ IB } & 90 & 3,75 a & $2,5 \mathrm{a}$ & $0 \mathrm{~b}$ & $0 \mathrm{~b}$ & $0 \mathrm{~b}$ \\
\hline & 180 & $2,25 \mathrm{a}$ & 3,75 a & $1,5 \mathrm{a}$ & $0 \mathrm{~b}$ & $0,25 \mathrm{~b}$ \\
\hline & 270 & 8,4 a & $8,25 \mathrm{a}$ & $1,1 \mathrm{~b}$ & $1,25 \mathrm{~b}$ & $0,25 \mathrm{~b}$ \\
\hline \multirow[t]{3}{*}{ DG } & 90 & $0 \mathrm{a}$ & 0,85 a & $0 \mathrm{a}$ & $0 \mathrm{a}$ & $0 \mathrm{a}$ \\
\hline & 180 & $3,5 \mathrm{a}$ & 5,6 a & $2,1 \mathrm{a}$ & $0 \mathrm{~b}$ & $0 \mathrm{~b}$ \\
\hline & 270 & $9,5 \mathrm{a}$ & $10,75 \mathrm{a}$ & $1,75 \mathrm{~b}$ & $0 \mathrm{c}$ & $0 \mathrm{c}$ \\
\hline \multirow[t]{3}{*}{$\mathrm{BC}$} & 90 & $2,45 \mathrm{a}$ & $2,5 \mathrm{a}$ & $2,0 \mathrm{a}$ & $0 \mathrm{~b}$ & $0 \mathrm{~b}$ \\
\hline & 180 & 5,45 a & $4,5 \mathrm{~b}$ & $2,1 \mathrm{~b}$ & $0 \mathrm{c}$ & $0 \mathrm{c}$ \\
\hline & 270 & $13,25 \mathrm{a}$ & $8,0 \mathrm{~b}$ & $2,25 \mathrm{c}$ & $0 \mathrm{~d}$ & $0 \mathrm{~d}$ \\
\hline \multirow[t]{3}{*}{ M5 } & 90 & $0,6 \mathrm{a}$ & $0,75 \mathrm{a}$ & $0 \mathrm{a}$ & $0 \mathrm{a}$ & $0 \mathrm{a}$ \\
\hline & 180 & $11,75 \mathrm{a}$ & $7,0 \mathrm{~b}$ & $0,5 \mathrm{c}$ & $0 \mathrm{c}$ & $0,1 \mathrm{c}$ \\
\hline & 270 & 15,25 a & $7,25 \mathrm{~b}$ & $0,35 \mathrm{c}$ & $0,5 \mathrm{c}$ & $0,6 \mathrm{c}$ \\
\hline \multirow[t]{3}{*}{$\mathrm{PQ}$} & 90 & $0 \mathrm{a}$ & $0 \mathrm{a}$ & $0 \mathrm{a}$ & $0 \mathrm{a}$ & $0 \mathrm{a}$ \\
\hline & 180 & $0 \mathrm{a}$ & $0,5 \mathrm{a}$ & $0 \mathrm{a}$ & $0 \mathrm{a}$ & $0 \mathrm{a}$ \\
\hline & 270 & $1,75 \mathrm{a}$ & $1,55 \mathrm{a}$ & $0,75 \mathrm{~b}$ & $0 \mathrm{~b}$ & $0 \mathrm{~b}$ \\
\hline \multirow[t]{3}{*}{ P 1} & 90 & $2,25 \mathrm{a}$ & $0 \mathrm{~b}$ & $0 \mathrm{~b}$ & $0 \mathrm{~b}$ & $0 \mathrm{~b}$ \\
\hline & 180 & 4,25 a & $1,2 \mathrm{~b}$ & $1,25 \mathrm{~b}$ & $0 \mathrm{~b}$ & $0 \mathrm{~b}$ \\
\hline & 270 & $5,5 \mathrm{a}$ & $4,75 \mathrm{a}$ & $1,25 \mathrm{~b}$ & $0 \mathrm{~b}$ & $0 \mathrm{~b}$ \\
\hline
\end{tabular}


of maçaranduba and pink ipê. At 270 days, the pine stakes installed at PYT, IV, IT, ICHS, BC and M5 were consumed more than other species, while consumption of pine was equal to that of Brazil nut and greater than that of all other species at IB, DG, PQ and P1. In general, pine was most susceptible to attack by $C$. gestroi, which reinforces the use of this wood as an indicator of termite activity, as suggested by Bultman and Southwell (1976).

The consumption of pine by $C$. gestroi reached a maximum of $15.25 \mathrm{~g}$ after 270 days. Studying the consumption of another exotic forest tree, Peralta et al. (2004) observed that $C$. gestroi was capable of consuming up to $14.62 \mathrm{~g}$ of wood from three different eucalyptus species in 60 days. Arab et al. (2005) estimated that the consumption rate of pine by $C$. gestroi was $26.8 \mathrm{~g}$ in 90 days. According to Bennett et al. (1996), the estimated consumption of different pine species by $C$. formosanus is between 0.02 and $0.381 \mathrm{~g}$ in 60 days, showing that this species is less voracious than C. gestroi. According to Bultman and Southwell (1976), C. formosanus is a highly voracious and extremely destructive Asiatic species that infests woods understood to be highly resistant to termite attack, making this species a good test organism for evaluating the natural resistance of wood to subterranean termites. However, the results of the present study indicate that C. gestroi is also a good test organism, perhaps better than C. formosanus.

The consumption of cabbage angelin, maçaranduba and pink ipê stakes did not differ significantly among sites, with the exception of $\mathrm{BC}$, where cabbage angelin was consumed more after 90 days. The same pattern was observed after 180 days at IT, IB, DG and BC and after 270 days at ICHS, DG and BC (Table 1).

In general, the consumption of all the species of wood by $C$. gestroi increased with time, suggesting that the resistance of the wood diminished during the period of exposure to the termites. At all sites, with the exception of PYT, IB and M5, the maçaranduba and pink ipê stakes were not consumed by $C$. gestroi until 270 days of exposure, indicating that these species are much more resistant to termite attack than cabbage angelin, Brazil nut and pine. However, the termites attacked the pink ipê stakes at 90 days at PYT and at 180 days at IB and M5, and they attacked the maçaranduba and pink ipê stakes at 270 days at all three sites. Still, the maximum consumed mass was only
$1.35 \mathrm{~g}$ (Table 1). These results corroborate those of Bultman and Southwell (1976), who observed, for example, that yellow ipê (Tabebuia chrysantha) stakes with dimensions of $3.8 \mathrm{~cm} \times 3.8 \mathrm{~cm} \times 45.7 \mathrm{~cm}$ exposed to the activity of wood biodegradation organisms for 30 months in the field suffered no damage from subterranean termites, showing traces of damage only after 7.5 years (90 months) of exposure. In the case of pine (Pinus sp.), severe damage was observed after only 12 months, and the stakes were completely destroyed after 30 months. These authors also observed that cabbage angelin stakes suffered no damage after 12 months of exposure in the field, but the stakes were completely destroyed after 30 months. It is probable that the high concentrations of compounds toxic to termites and the high wood densities of the native species studied are factors that provide resistance to the activity of these degrading insects, as demonstrated by Bultman and Southwell (1976).

The residential neighborhood (RE) was the only site at which the stakes were not consumed by $C$. gestroi (Table 1). However, the presence of this termite has been reported in this area by Bicalho (2000) and Peralta (2001). It is probable that the lack of consumption of the stakes was caused by the high availability of food in this area, ranging from fallen twigs to trees, which are commonly attacked by $C$. gestroi in urban areas (FONTES and ARAÚJO, 1999). According to Duryea (2006), degrading litter can provide necessary food while subterranean termites forage for other cellulosic material in or around residences.

The results of the present study indicate that pine and Brazil nut are not recommended for use in the furniture and civil construction industries, requiring (especially for civil construction) prior evaluation for the presence of subterranean termites. On the other hand, cabbage angelin, maçaranduba and pink ipê are appropriate for these uses because they demonstrate greater resistance to termites under field conditions.

Evaluation of the resistance or susceptibility of forest species to termites under natural conditions is increasingly important in determining appropriate uses of various woods. Such studies may contribute to a reduction in the use of chemical preservatives for wood treatment. Utilization of wood with high resistance to termites tends to diminish the need for additional preventative measures to increase wood durability. 


\section{CONCLUSIONS}

- Pine and Brazil nut are susceptible to Coptotermes gestroi attack, while cabbage angelin, maçaranduba and pink ipê are more resistant to the activity of these subterranean termites.

- Density is a determining parameter in the resistance of woods to attack by $C$. gestroi.

- Pine stakes can serve as indicators of termite activity when testing the natural resistance of other woods to subterranean termites.

\section{REFERENCES}

ABREU, R. L. S.; SILVA, K. E. S. Resistência natural de dez espécies de madeiras da Amazônia ao ataque de Nasutitermes macrocephalus (Silvestre) e $N$. surinamensis (Holmgren) (Isoptera: Termitidae). Revista Árvore, v.24, n.2, p.229-234, 2000.

ARAB, A. et al. Foraging activity and demographic patterns of two termite species (Isoptera: Rhinotermitidae) living in urban landscapes in southeastern Brazil. European Journal of Entomology, v.102, n.4, p.691-697, 2005.

BARBOSA, A.P. et al. Efeito tóxico de componentes químicos de madeiras da Amazônia com relação a térmitas. In: CONGRESSO FLORESTAL

BRASILEIRO, 8., 2003. São Paulo: Sociedade Brasileira de Silvicultura; Brasília: Sociedade Brasileira de Engenheiros Florestais, 2003.1 CDROM.

BEHR et al. Influence of wood hardness on feeding by the eastern subterranean termite, Reticulitermes flavipes (Isoptera: Rhinotermitidae). Annals of the Entomological Society of America, v.65, n.2, p.457-460, 1972.

BENNETT, G.W. et al. Termitas subterráneas. In: BENNETT, G.W. et al. Guía científica de Truman para operaciones de control de plagas. Cleveland: Advanstar Communications, 1996. p.149-163.

BERTI FILHO, E. Cupins e florestas. IN: BERTI FILHO, E.; FONTES, L.R. (Eds.). Alguns aspectos atuais da biologia e controle de cupins. Piracicaba: FEALQ, 1995. p.127-140.
BICALHO, A.C. Aspectos

comportamentais, taxa de consumo e marcação do cupim subterrâneo Coptotermes havilandi Holmgren, 1911 (Isoptera: Rhinotermitidae) em área residencial. 2000. 82f. Dissertação (Mestrado em Agronomia) - Universidade Federal de Lavras, Lavras, 2000.

BULTMAN, J.D. et al. Natural resistance of some tropical African woods to Coptotermes formasanus Shiraki. Forest Products Journal, v.29, n.6, p.46-51, 1979.

BULTMAN, J.D.; SOUTHWELL, C.R. Natural resistance of tropical American woods to terrestrial wood-destroying organisms. Biotropica, v.8, n.2, p.71-95, 1976.

CAVALCANTE, M.S. Deterioração biológica e preservação de madeiras. São Paulo: IPT, 1982. 40p. (Pesquisa e Desenvolvimento, 8).

CONSTANTINO, R. Chave ilustrada para identificação dos gêneros de cupins (Insecta: Isoptera) que ocorrem no Brasil. Papéis Avulsos de Zoologia, v.40, n.25, p.378-448, 1999.

DURYEA, M.L. Landscape mulches: will subterranean termites consume them? Gainesville: IFAS Extension, University of Florida, 2006. 4p.

EDWARDS, R.; MILL, A.E. Termites in buildings: their biology and control. Felcourt: Rentokil, 1986. 231p.

EVANS, T.A. Tunnel specificity and forager movement in subterranean termites (Isoptera: Rhinotermitidae and Termitidae). Bulletin of Entomological Research, v. 92, n.3, p. 193209,2002

FONTES, L.R.; ARAÚJO, R.L. Os cupins. In: MARICONI, F.A.M. (Coord.). Insetos e outros invasores de residências. Piracicaba: FEALQ, 1999. p.35-90.

HUNT, G.M.; GARRATT, G.A. Wood preservation. 3.ed. New York: McGraw Hill, 1967. 433p.

R. Árvore, Viçosa-MG, v.33, n.6, p.1043-1050, 2009 
OLIVEIRA, A.M.F. et al. Agentes destruidores da madeira. In: LEPAGE, E. S. (Coord.) Manual de preservação de madeiras. São Paulo: IPTSICCT, 1986, v.1, p.99-279.

LENZ, M.; ZI-RANG, D. On the validity of using susceptible timbers as indicators of termites vigours in laboratory studies on the resistance of materials to termites. Material und

Organismen, v.20, n.2, p.97-108, 1985.

LONG, C.E.; THORNE, B.L. Resource fidelity, brood distribution and foraging dynamics in complete laboratory colonies of Reticulitermes flavipes (Isoptera: Rhinotermitidae). Ethology, Ecology \& Evolution, v.18, n.2, p. 113-125, 2006.

LOPEZ, G.A.C; MILANO, S. Avaliação da durabilidade natural da madeira e de produtos usados na sua proteção. In: LEPAGE, E.S. (Coord.). Manual de preservação de madeira. São Paulo: IPT-SICCT, 1986, v.1, p.473-510.

LORENZI, H. Árvores brasileiras: manual de identificação e cultivo de plantas arbóreas nativas do Brasil. Nova Odessa: Plantarum, 1992. 352p.

MOORE, H. Wood-inhabiting insects in houses: their identification, biology, prevention and control. Washington: U.S. Department of Agriculture Forest Service and Department of Housing and Urban Development, 1979. 133p.

PAES, J.B. et al. Resistência natural de nove espécies de madeiras do semi-árido brasileiro a fungos xilófagos em condições de laboratório. Revista Árvore, v.28, n.2, p.275-282, 2004.

PERALTA, R.C.G. et al. Wood consumption rates of forest species by subterranean termites (Isoptera) under field conditions. Revista Árvore, v.28, n.2, p. 283-289, 2004.

R. Árvore, Viçosa-MG, v.33, n.6, p.1043-1050, 2009
PERALTA, R.C.G. Preferência alimentar e consumo de madeiras de quatro essências florestais por térmitas subterrâneos (Isoptera: Rhinotermitidae e Termitidae). 2001. 55f. Dissertação (Mestrado em Biologia Animal) - Universidade Federal Rural do Rio de Janeiro, Seropédica, 2001.

PESAGRO-RIO. Informativo meteorológico para o município de Itaguaí. RJ. Seção de Climatologia. 1990, 13p.

RUYOOKA, D.B.A. Response of Nasutitermes exitiosus (Hill) (Termitidae) do decay fungus- and fungal isolate "B 8"- infested wood. Zeitschrift für Angewandte Entomologie, v.88, p.132143,1979 .

SANDS, W.A. The association of termites and fungi. In: KRISHNA, K.; WEESNER, T.M. (Eds). The biology of termites. New York: Academic Press, 1969. p.495-524.

TREVISAN, H.T.F. et al. Avaliação de propriedades físicas e mecânicas da madeira de cinco espécies florestais em função da deterioração em dois ambientes. Revista Árvore, v.31, n.1, p.93-101, 2007.

TSUNODA, K. The natural resistance of tropical woods against biodeterioration. Wood Research, v.77, p.18-27, 1990.

TRUGILHO, P.F. et al. Comparação de métodos de determinação da densidade básica em madeira. Acta Amazônica, v.20, n.único, p.307-319, 1990.

VITAL, B.R. Métodos de determinação da densidade da madeira. Viçosa: Sociedade de investigações Florestais, Universidade Federal de Viçosa, 1984, 21p. (SIF. Boletim técnico, 01).

WILLIAMS, R.M.C. Termite infestation of pines in British Honduras. London: H.M. Stationery Office, 1965. 31p. (Overseas Research Publications, 11). 